Original Article

\title{
BIOACTIVE COMPOUNDS FROM SPONGE SUBERITES CARNOSUS (JOHNSTON) COLLECTED FROM WEST COAST OF MUMBAI, INDIA
}

\author{
BHADEKAR N. S., ZODAPE G. V. \\ Department of Zoology, S. S. and L. S. Patkar College of Arts and Science and V. P. Varde College of Commerce and Economics, S. V. Road, \\ Goregaon West, Mumbai 400062, India \\ Email: drgautamvz5@gmail.com
}

Received: 15 Jan 2021, Revised and Accepted: 21 Apr 2021

ABSTRACT

Objective: Structural elucidation of bioactive compounds from marine Sponge Suberites Carnosus (Johnston) by using Thin Layer Chromatography (TLC), Gas Chromatography-Mass Spectrometry (GC-MS), Fourier Transform Infrared Spectrometer (FTIR) techniques with respect to its pharmacological and biomedical properties.

Methods: The sponge Suberites carnosus (Johnston) was collected during low tides from West Coast of Mumbai. Crude extract was obtained by taking 10 gram of sponge sample in $10 \mathrm{ml}$ of methanol. The preparative TLC (Thin Layer Chromatography) was performed by using Toluene: Ethyl acetate: Diethylamine (7:2:1) (v/v). The isolated compounds were subjected to GC-MS and FTIR analysis.

Results: From the GC-MS and FTIR analysis, total ten compounds were identified. The GC-MS spectra correlate to the mass spectra. The structures of those compounds are 6-Fluoro 2-trifluromethylbenzoic acid,2,3-dichlorophenyl ester, Eicosane 3-cyclohexyl, Phosphine imide, P,P,P,-tris (p-chlorophenyl)-Nphenyl-, Dimethylhyl hexavinyl octasilsesquioxane, Hexanoicacid, hexadecyl ester, Hexadecanoic acid,2-hydroxy1-(hydroxymethyl)ethyl ester, 9, 19Cyclolanostan-3-ol, acetate, (3ß), Tetracosane, 3-ethyl-, 11, 14-Eicosadienoic acid, methyl ester, Triacontane, 11,20-didecyl-respectively.

Conclusion: The nature and biological properties of the said compounds were determined and it was found that some of them act as a skin irritant. Some of them have fatty, metabolite, and irritant property, whereas some are act as masking and perfuming agents. Some compounds are highly toxic property, whereas others have an effect on health and environmental hazard. Some are highly corrosive in nature, whereas others are Cholesterol and chemotaxonomic significance.

Keywords: Sponge, Bioactive compounds, Analytical study

(C) 2021 The Authors. Published by Innovare Academic Sciences Pvt Ltd. This is an open access article under the CC BY license (https://creativecommons.org/licenses/by/4.0/) DOI: https://dx.doi.org/10.22159/ijpps.2021v13i6.40794. Journal homepage: https://innovareacademics.in/journals/index.php/ijpps.

\section{INTRODUCTION}

There is a worldwide interest in marine natural products as one of the few de novo sources of drug discovery [1]. Sponges offer a rich source of unique and diverse natural products. Marine sponges are potential sources of unique bioactive metabolites and many of these compounds are valuable for medicinal uses. There are between 9,000 and 15,000 species of sponges. Sponges generally reside in polar shelves as they have a unique ability to filter small food particles from passing water. They provide a high amount of bioactive compounds. The sponge class Demospongiae is known for producing the largest number and diversity of secondary metabolites isolated from marine invertebrates [2]. Sponges are categorized under filter-feeding animals because of their ability to filter bacteria from the inhalant water current. The living tissues in combination with some antibiotic agents provide an enhanced microbial defense. The microbial growth control ability of sponge extracts has been demonstrated by use of simple laboratory experiments using bacterial cultures [3]. A total of 486 sponge species have been found in Indian waters [4]. However, the bioactive potential of compounds from Indian sponges has been little studied. Undoubtedly, the Indian scenario for marine pharmacology is still in nascent phase, but there is potential to tap the resources in a much better way to explore treatments for various clinical ailments. Although there are only a few marine-derived products currently in the market, several new compounds from marine origin are now under clinical trials for drug development. While the marine world offers an extremely rich resource for novel compounds, it also represents a great challenge that requires multidisciplinary approach to bring the marine chemical diversity up to its therapeutic potential. The work carried out by NIO [5] and others consist of bioactivity of the compounds collected from the coast of south and southeast India. A very novel work has been reported by
[6] CIFE Mumbai, and very little effort has gone into unraveling the details on the bioactive compounds. However, [7] have isolated and characterized the bioactive compounds from Intertidal crab Leptodius exratus collected from Nariman Point coast of West Coast of Mumbai. Therefore the present study comprises an initial effort to assess the bioactivity of secondary metabolites from the marine subtidal sponges Suberites carnosus (Johnston) from Mumbai coasts and its extract was investigated for the presence of bioactive compounds.

\section{MATERIALS AND METHODS}

\section{Collection of samples}

The sponges Suberites carnosus (Johnston) were collected during low tides from West Coast of Mumbai. The sponge was taken alive in seawater to the Department of Zoology, laboratory at the PatkarVarde College Goregaon (west), Mumbai, India. The samples were washed under seawater and then in distilled water and sun-dried.

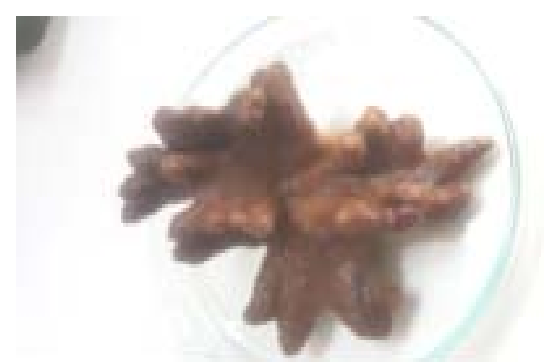

Fig. 1: Specimen of marine sponge Suberites carnosus [Johnston, 1842] collected from Mumbai coast 


\section{Identification of sponges}

Preliminary identification was done by studying the shape and size of the spicules and by refereeing the relevant literature. The confirmation of identification was done by Dr. P. A. Thomas, Principal Scientist, Central Marine Fisheries Research Institute (CMFRI), Thiruvananthapuram, Kerala.

\section{Preparation of sponge extracts}

Crude extract was obtained following the method of [8] with some modifications. To 10 gram of sponge samples, $10 \mathrm{ml}$ of methanol was added and kept standing for $24 \mathrm{~h}$. Solvent was then removed, by squeezing sponge samples, and filtered through Whatman filter paper no. 1. The remaining solvent was evaporated at low pressure using Rotary Vacuum Evaporator at $45{ }^{\circ} \mathrm{C}$. The resultant compound was subjected to Millipore filter system and finally dried in a vacuum desiccator and stored at $4{ }^{\circ} \mathrm{C}$ in a refrigerator till further use.

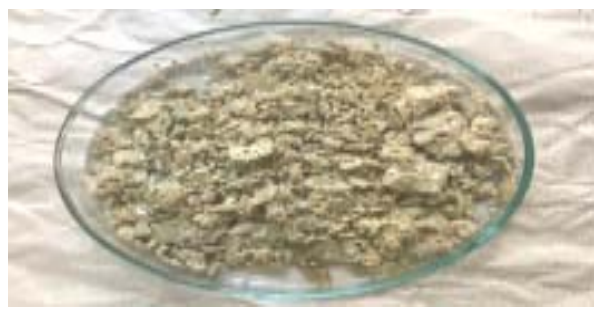

Fig. 2: Crude extract of marine sponge Suberites carnosus [Johnston, 1842] collected from Mumbai coast

\section{Ethical approval}

Ethical approval was sought from Maharashtra State Biodiversity Board, Nagpur, Maharashtra, India, for the collection of marine sponge Suberites carnosus [Johnston, 1842] from Mumbai coast to carry out the research. As per the guidelines by the State Biodiversity Board, the voucher specimens of Suberites carnosus, deposited at the repository center at NIO Goa, India. The Voucher number of specimen was 2-NI01007/18 (Suberites carnosus).

\section{Partial purification and analytical study}

\section{TLC analysis}

Chem. Tech. CAMAG, TLC model of HPTLC (High-Performance Thin Layer Chromatography) available at Ancrom test lab. Mulund,
Mumbai was used for the analysis of the samples. For preparative TLC, $10 \mathrm{ml}$ of the crude extract was spotted on a preparative TLC (Thin Layer Chromatography) as the stationary phase pre-coated aluminium plates with silica gel $\left(60 \mathrm{~F}^{254}\right)$ (thickness $0.5 \mathrm{~mm}$ ), dried and kept in the saturated twin trough chamber containing Toluene: Ethyl acetate: Diethylamine (7:2:1) (v/v) as a mobile phase and developed up to $9 \mathrm{~cm}$ length. The plate was removed and dried. The development of the sample spots was done using twin trough chamber. The Deutorium lamp at $254 \mathrm{~nm}$ was used for densitometric scanning of the samples. The spots were so obtained were scrapped off and dissolved in methanol and filtered and evaporated to dryness to get pure compounds. The pure compounds so obtained were subjected to analytical study.

\section{GC-MS (Gas chromatography mass specrometry) analysis}

The powdered form samples were analyzed at IIT (SAIF) Powai, Mumbai. Analysis was performed with Jeol model Accu TOF GCV, GC MS (EI+ve or-ve) was used which has Mass range of 10-2000 amu and Mass resolution-of 6000 .

\section{FTIR (Fourier transform infrared spectroscopy) analysis}

The samples were analyzed at IIT (SAIF) Powai, Mumbai. Analysis was performed with Bruker instrument corporation Germany make, 3000 Hyperion Microscope with Vertex 80 FTIR System model was used. The scanning was done in the range of $4000-900 \mathrm{~cm}^{-1}$.

All chemicals and solvents used were of analytical grade supplied by M/S SD fine chemicals, Thane, (India)

\section{RESULTS AND DISCUSSION}

\section{Characterization of isolated extracts of sponge by HPTLC}

The extracts isolated from the Suberites carnosus (Johnston) collected from Nariman Point Mumbai coast are spotted on HPTLC plates and the plates were developed in a twin-trough chamber using Toluene: Ethyl acetate: Diethylamine (7:2:1) (v/v), as a mobile phase. The plates were dried and sprayed with the dragendroff reagent. The photograph of the HPTLC plate of Suberites carnosus (Johnston) is shown in Photograp 1 and fig. 3.

The spraying reagents gave positive tests for the presence of amides. The distinct and well-separated three spots were at Rf values of Suberites carnosus (Johnston) well-separated four spots were at Rf values R1-0.650; R2-0.690; R3-0.75; and R4-0.89 were recorded. The densitometric scanning of these spots resulted in the quantification of these substances are found to be (28.3\%); (32.6\%); (8.89\%) and (30.21\%) respectively.

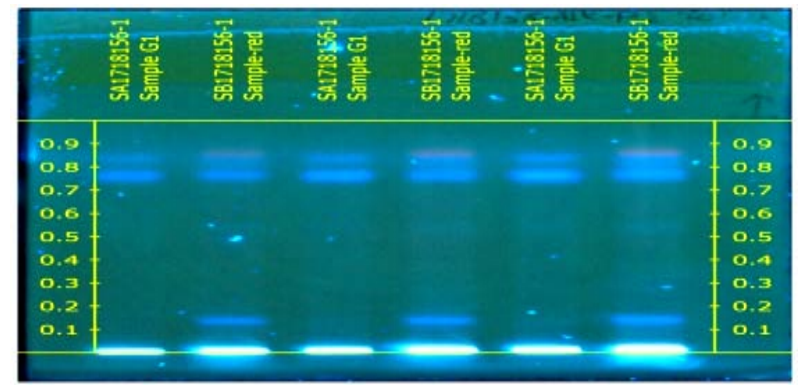

Photograph 1: TLC of crude extracts of sponge Suberites carnosus

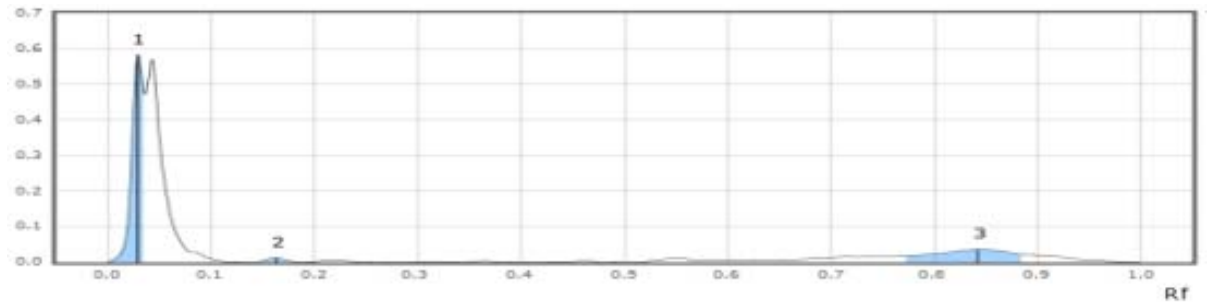

Fig. 3: Graph showing isolated compounds of crude extracts of sponge Suberites carnosus 


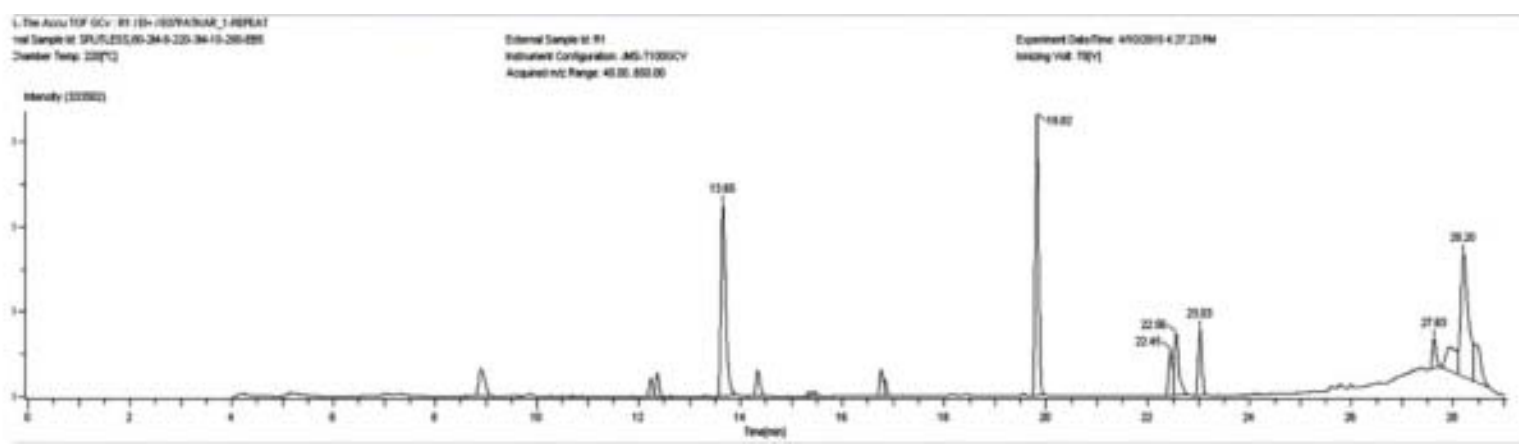

Fig. 4: Gas chromatogram isolated compound 1 of Suberites carnosus

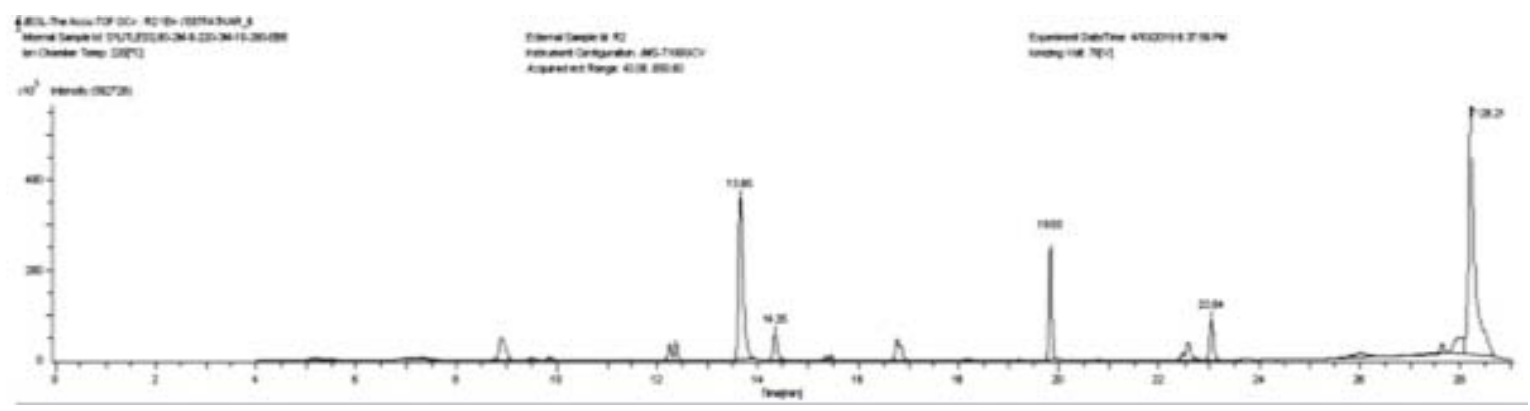

Fig. 5: Gas chromatogram isolated compound 2 of Suberites carnosus

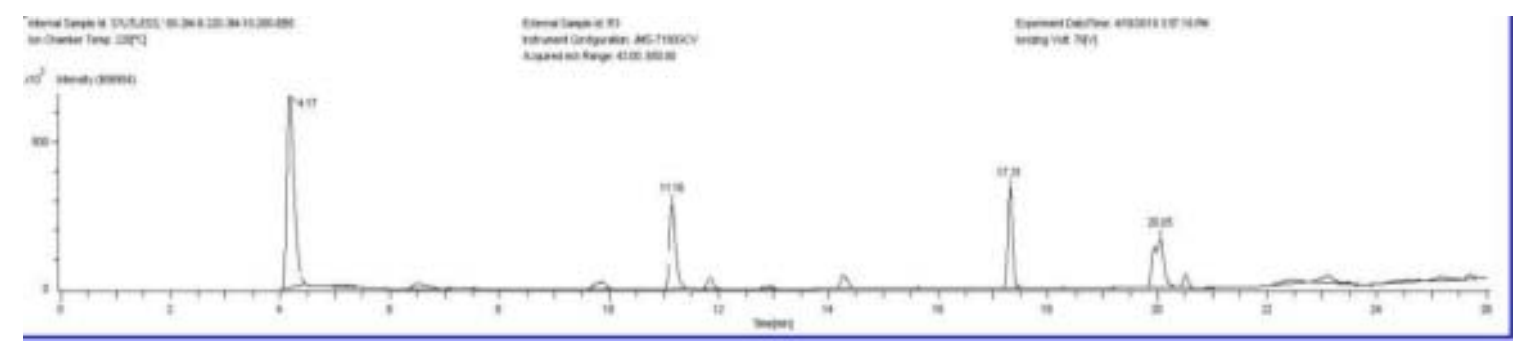

Fig. 6: Gas chromatogram isolated compound 3 of Suberites carnosus

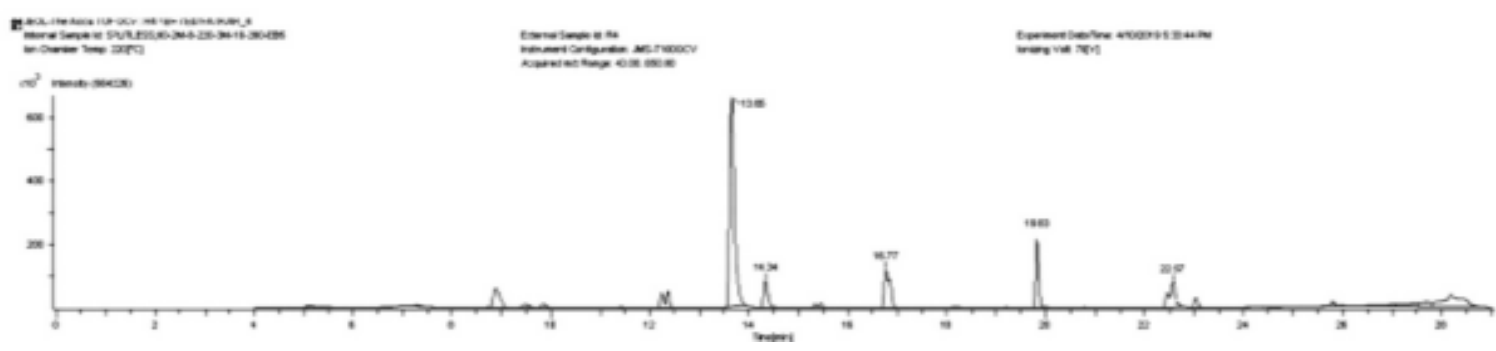

Fig. 7: Gas chromatogram isolated compound-4 of Suberites carnosus

\section{Characterization of isolated extracts of sponge on GC-MS}

GC-MS of the extracts isolated from the Suberites carnosus (Johnston) have been performed and the results are presented in fig. 4-7

The gas chromatograms of the extracts of the Suberites carnosus (Johnston) shown in fig. 4 to 7 indicate that there are a large number of peaks. However the peaks at Rt value of of Suberites carnosus (Johnston) are $14.34 ; 15.35 ; 15.45 ; 16.76 ; 27.63 ; 28.21 ; 4.17 ; 6.49$; 19.93; and 12.36 were found suitable for identification. The other peaks could not be identified due to the lack of a database in the library as well as any references that are reported till now for theSuberites carnosus (Johnston). The GC peaks obtained at Rt value of Suberites carnosus (Johnston) are 14.34; 15.35; 15.45; 16.76; $27.63 ; 28.21 ; 4.17 ; 6.49 ; 19.93$; and 12.36 were only employed for recording the mass spectra by irradiating the eluents at these Rt values through electron impact $\left(\mathrm{EI}^{+}\right)$source of the Mass spectrometer.

Fig. 8 to 17 are the mass spectra of eluted compounds at Rt values $14.34 ; 15.35 ; 15.45 ; 16.76 ; 27.63 ; 28.21 ; 4.17 ; 6.49 ; 19.93 ; 12.36$ respectively. The $\mathrm{M} / \mathrm{Z}$ mass peaks obtained for eluents at Rt values $14.3415 .35 ; 15.45 ; 16.76 ; 27.63 ; 28.21 ; 4.17 ; 6.49 ; 19.93 ; 12.36$ corresponds to the substances of molecular mass of isolated compounds of Suberites carnosus (Johnston) are 352, 364, 455, $608,340,330,470,366,322$, and 702 , respectively. It is observed 
that the mass spectra obtained for Suberites carnosus (Johnston) all the compounds are found dissimilar indicating that the different substances (compounds) are present in all isolated compounds of Suberites carnosus (Johnston).

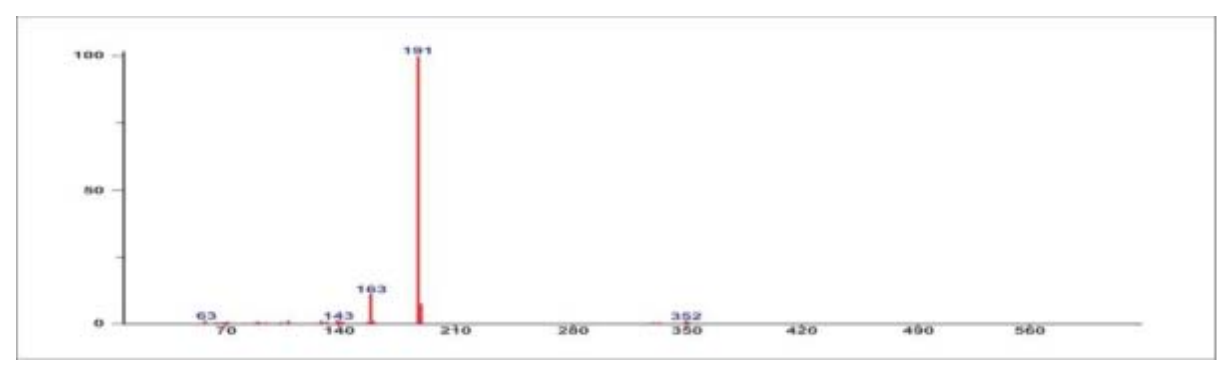

Fig. 8: Compound 1-6-Fluoro-2-trifluoromethylbenzoic acid, 2,3-dichlorophenyl ester Formula- $\mathrm{C}_{14} \mathrm{H}_{6} \mathrm{Cl}_{2} \mathrm{~F}_{4} \mathrm{O}$

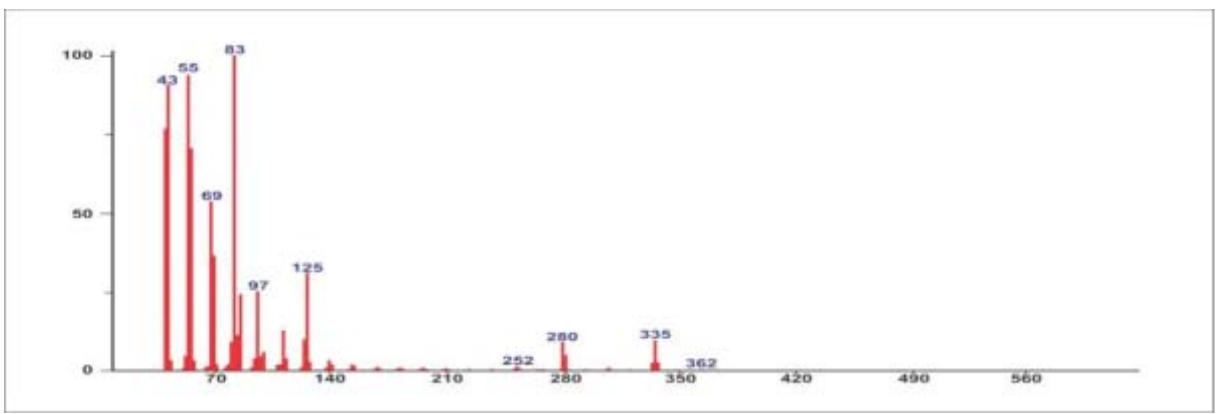

Fig. 9: Compound 2-Eicosane, 3-cyclohexyl-Formula- $\mathrm{C}_{26} \mathrm{H}_{52}$

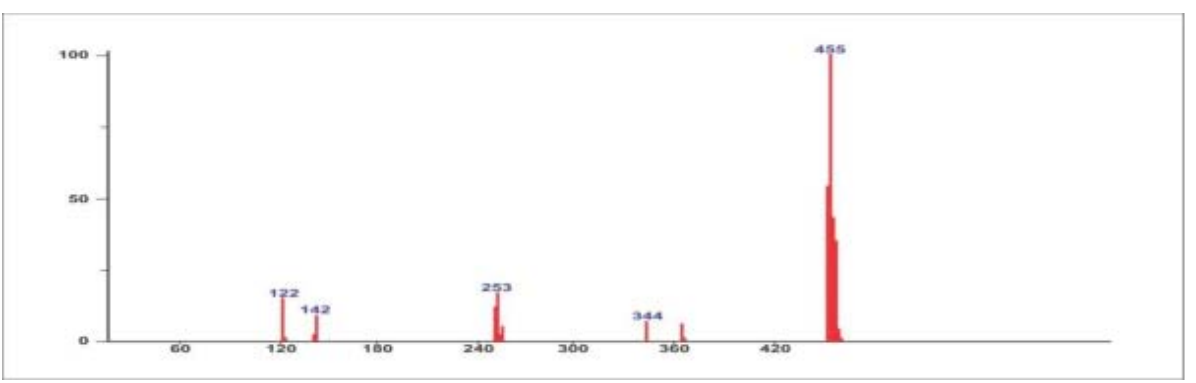

Fig. 10: Compound 3-Phosphine imide, P,P,P-tris (p-chlorophenyl)-N-phenyl-Formula- $\mathrm{C}_{24} \mathrm{H}_{17} \mathrm{Cl}_{3} \mathrm{NP}$

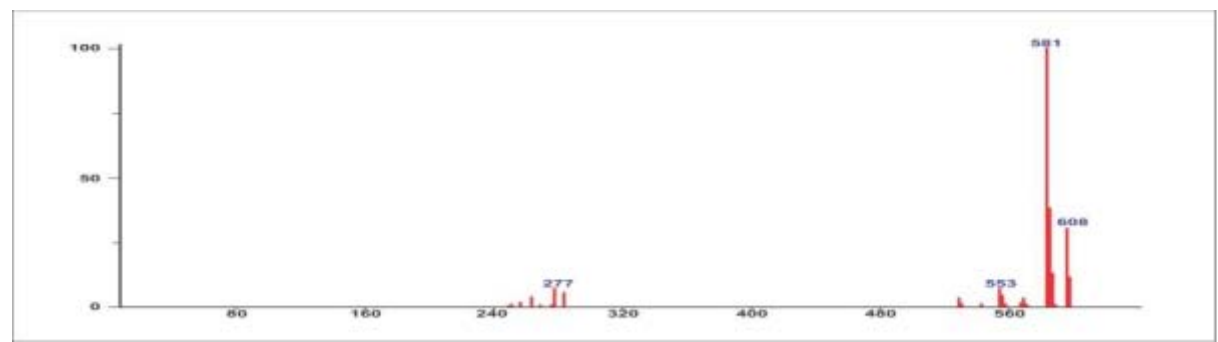

Fig. 11: Compound 4-dimethyl hexavinylo ctasilses quioxane formula- $\mathrm{C}_{14} \mathrm{H}_{24} \mathrm{O}_{12} \mathrm{Si}_{8}$

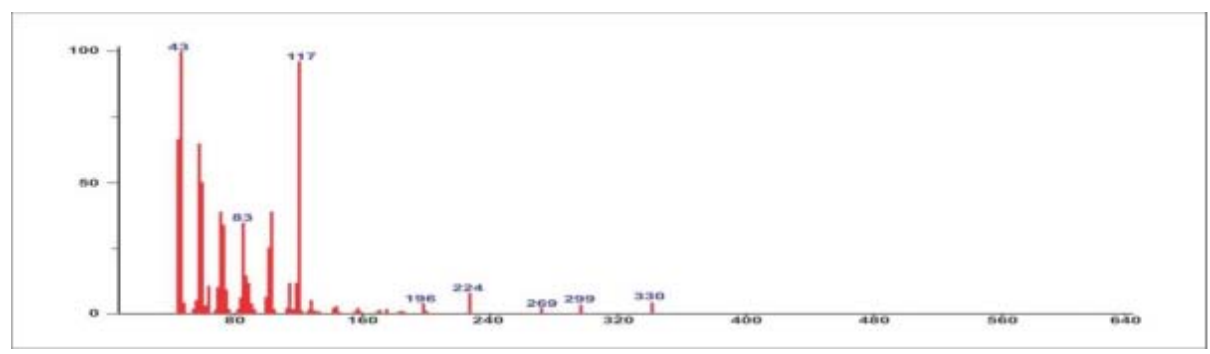

Fig. 12: Compound 5-Hexanoic acid, hexadecyl ester Formula- $\mathrm{C}_{22} \mathrm{H}_{44} \mathrm{O}_{2}$ 


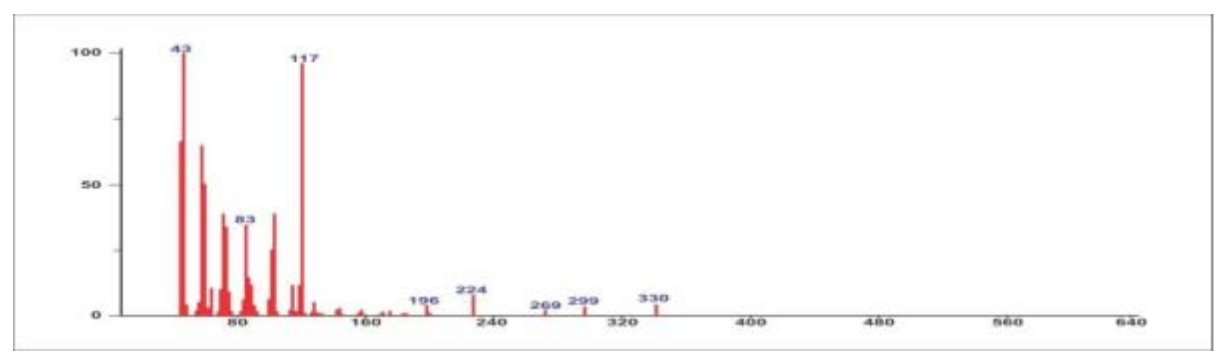

Fig. 13: Compound 1-hexadecanoic acid,2-hydroxy-1-(hydroxymethyl) ethyl ester Formula- $\mathrm{C}_{19} \mathrm{H}_{38} \mathrm{O}_{4}$

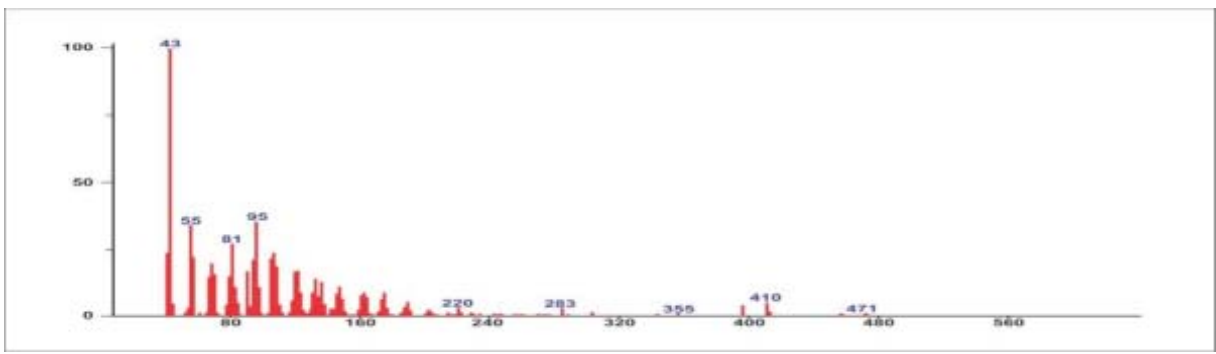

Fig. 14: Compound 1-9,19-Cyclolanostan-3-ol, acetate, (3ß)-Formula- $\mathrm{C}_{32} \mathrm{H}_{54} \mathrm{O}_{2}$

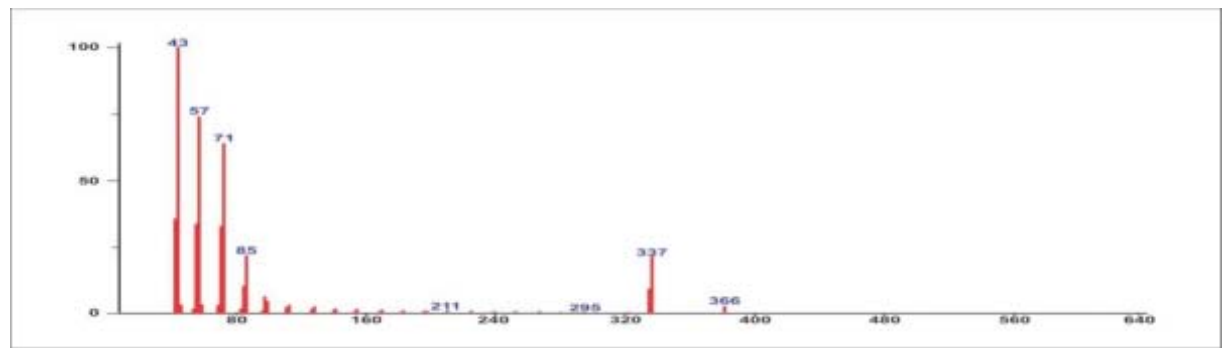

Fig. 15: Compound 2-tetracosane,3-ethyl-formula- $\mathrm{C}_{26} \mathrm{H}_{54}$

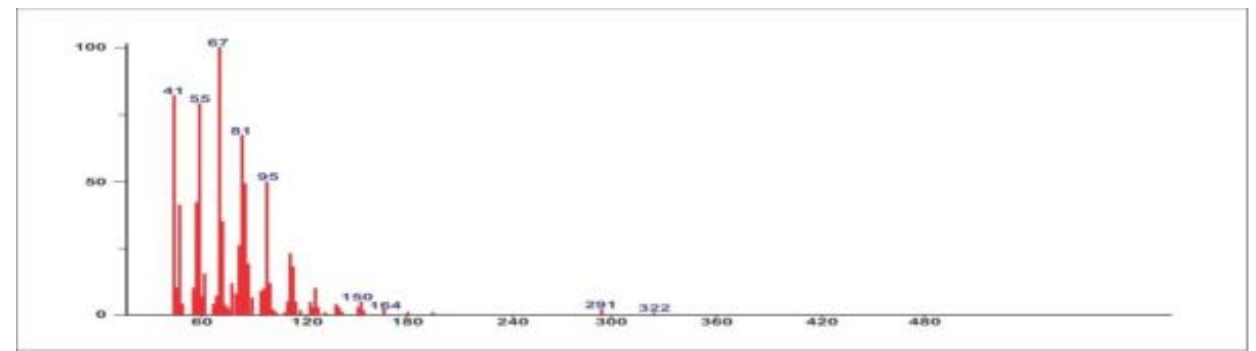

Fig. 16: Compound 3-11,14-Eicosadienoic acid, methyl ester Formula- $\mathrm{C}_{21} \mathrm{H}_{38} \mathrm{O}_{2}$

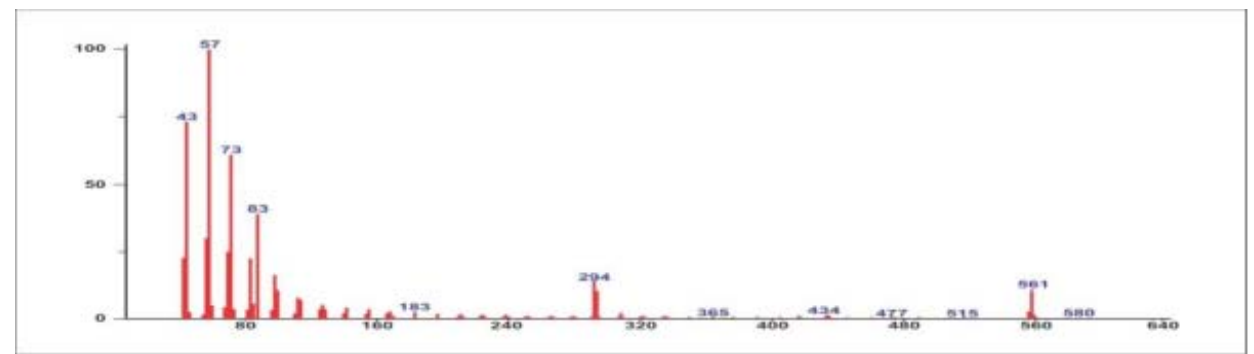

Fig. 17: Compound 1-Triacontane, 11,20-dodecyl-formula- $\mathrm{C}_{50} \mathrm{H}_{1} \mathrm{O}_{2}$

The fragmentation peaks obtained for each of the mass spectra are as follows: Rt value of compound $1 / 1$ at 14.34 are $\mathrm{M} / \mathrm{Z}$ at 352 (5\%),
M/Z 191(100\%), M/Z 163 (15\%), M/Z 143 (2\%), and M/Z 63 (2\%). Rt value of compound $1 / 2$ at 15.35 are $M / Z 364$ (2\%), M/Z 
335(5\%), M/Z 280(4\%),M/Z 252 (2\%),M/Z 125 (38\%),M/Z 83 $(100 \%), M / Z 69(54 \%)$, and M/Z 55 (90\%). Rt value of compound $1 / 3$ at 15.45 are $\mathrm{M} / \mathrm{Z} 455(100 \%), \mathrm{M} / \mathrm{Z} 344(7 \%), \mathrm{M} / \mathrm{Z} 253(8 \%), \mathrm{M} / \mathrm{Z}$ 142 (5\%), and $M / Z$ at $122(6 \%)$. Rt value of compound $1 / 4$ at 16.76 are M/Z 608 (27\%), M/Z 581(100\%), M/Z 553(4\%), and M/Z 277 (4\%). Rt value of compound $1 / 5$ at 27.63 are $\mathrm{M} / \mathrm{Z} 340(1 \%), \mathrm{M} / \mathrm{Z}$ 269(2\%), M/Z 224(6\%), M/Z 196 (4\%), M/Z 117(95\%), and M/Z 43(100\%). Rt value of compound 2 at 28.21 are $\mathrm{M} / \mathrm{Z} 330(7 \%), \mathrm{M} / \mathrm{Z}$ 299 (12\%),M/Z 239 (78\%),M/Z 134 (60\%),M/Z 98 (67\%),M/Z 74 $(62 \%)$,and $\mathrm{M} / \mathrm{Z} 43(100 \%)$. Rt value of compound $3 / 1$ at 4.17 areM/Z 470 (2\%),M/Z 410(5\%),M/Z 355 (1\%),M/Z 283 (4\%),M/Z $220(5 \%), M / Z$ 95(38\%),and M/Z 43 (100\%). Rt value of compound $3 / 2$ at 6.49 are $\mathrm{M} / \mathrm{Z} 366(0.1 \%), \mathrm{M} / \mathrm{Z} 337(20 \%), \mathrm{M} / \mathrm{Z} 295(1 \%), \mathrm{M} / \mathrm{Z}$ 211 (1\%), M/Z 85(22\%), M/Z 71(62\%), and M/Z 43 (100\%). Rt value of compound $3 / 3$ at 19.93 are $\mathrm{M} / \mathrm{Z} 322(2 \%), \mathrm{M} / \mathrm{Z}$ 291(3\%),M/Z 164 (3\%),M/Z 150 (5\%),M/Z 95 (51\%),M/Z 87 $(100 \%)$,and $\mathrm{M} / \mathrm{Z} 55(61 \%)$. Rt value of compound 4 at 12.36 are M/Z 702 (1\%),M/Z 580(1\%),M/Z 561 (5\%),M/Z 294 (12\%),M/Z 9183(3\%),M/Z 85 (43\%),M/Z 57 (100\%),and M/Z 43 (62\%).

\section{FTIR (Fourier transform infrared spectroscopy) analysis}

The FTIR studies are carried out in $\mathrm{KBr}$ pellets. Each of the compounds isolated at Rf values at R1-0.650; R2-0.690; R3-0.75; and R4-0.89 on TLC for each of the isolated compounds of Suberites carnosus (Johnston) extracts gave the IR spectras as shown in fig. 18 to 21. All the IR spectra's of the compounds at the respective Rf values mentioned above are found to be dissimilar and different of the extracts isolated from Suberites carnosus (Johnston).

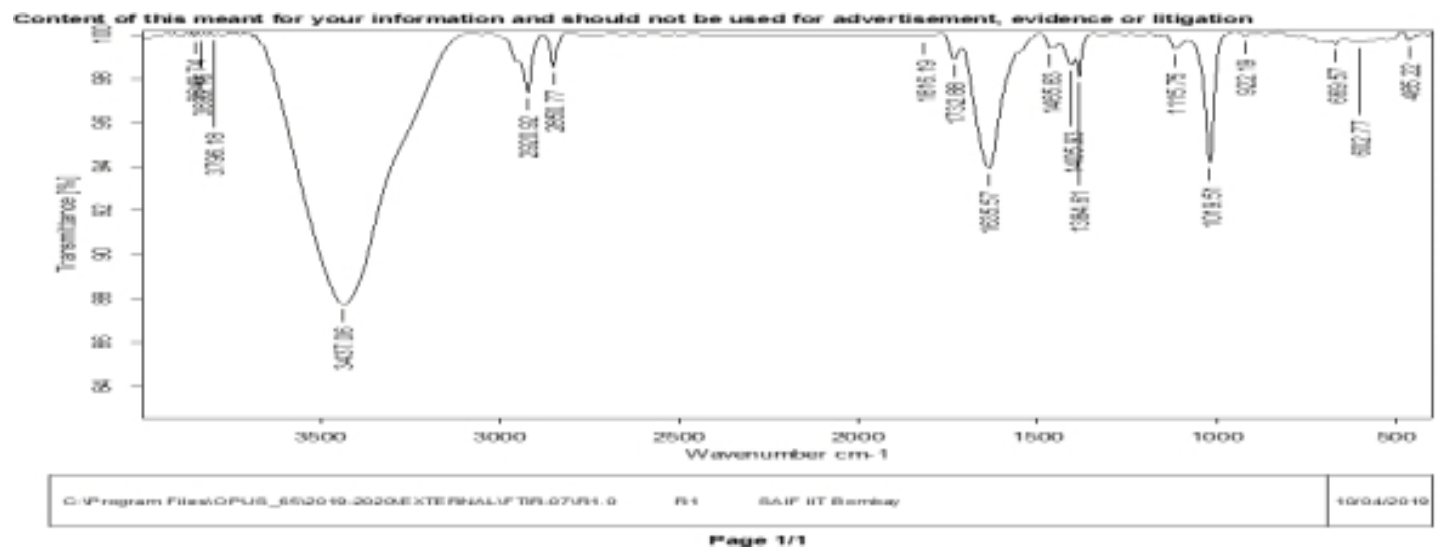

Fig. 18: FTIR spectra of isolated compound-1 of Suberites carnosus

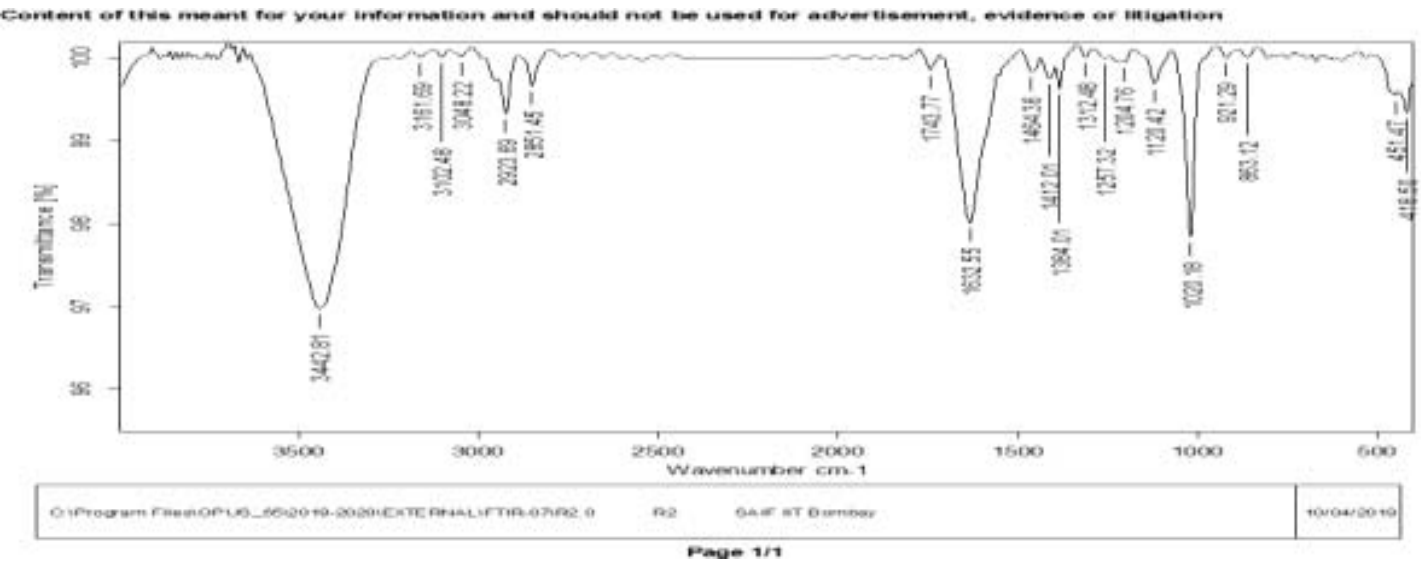

Fig. 19: FTIR spectra of isolated compound-2 of Suberites carnosus

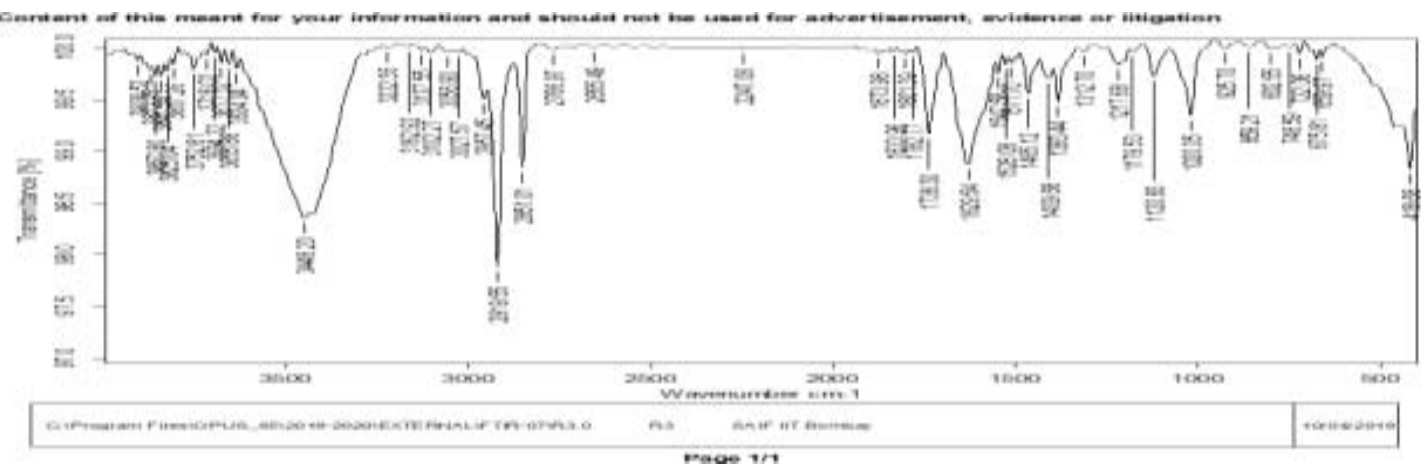

Fig. 20: FTIR spectra of isolated compound-3 of Suberites carnosus 


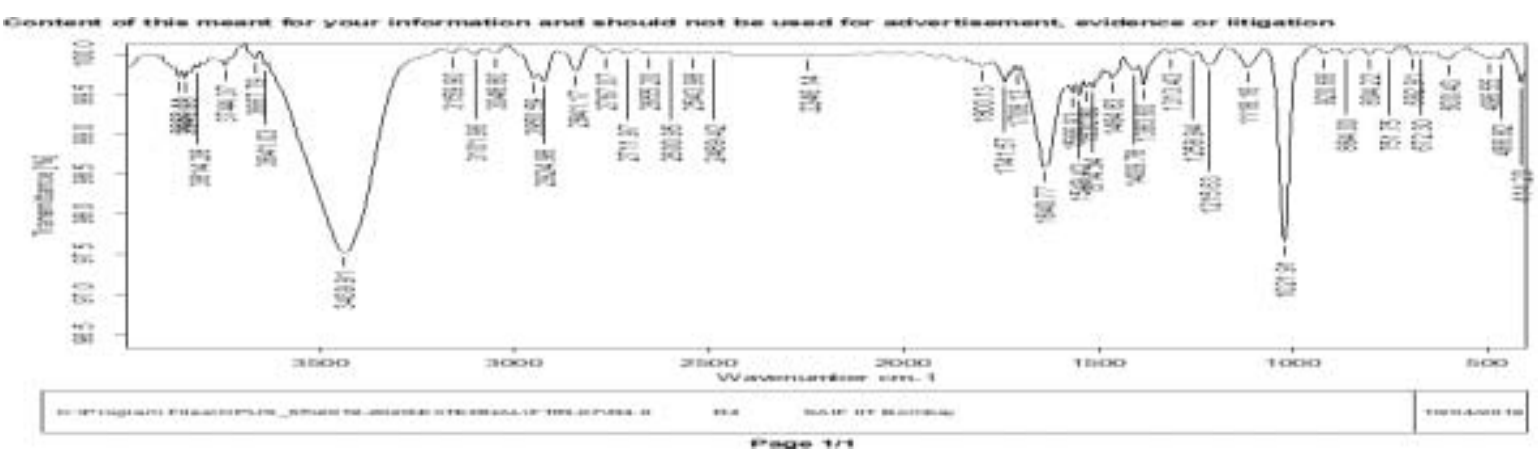

Fig. 21: FTIR spectra of isolated compound-4 of Suberites carnosus

The wavenumbers of some of the important IR peaks along with their intensity, type of vibration and probable groups present in the respective compounds isolated at Rf values R1-0.650; R2-0.690; R30.75 ; and R4-0.89 are as shown in table.

Table 1: Correlation of IR spectra of the compound isolated from Suberites carnosus at Rf value 0.650 on TLC

\begin{tabular}{llll}
\hline S. No. & Wavenumber: cm-1 intensity & Type of Ir vibrations & Probable group assignment \\
\hline 1 & 3849.74 & $\mathrm{~N}-\mathrm{H}, \mathrm{C}-\mathrm{H}-\mathrm{stretching}$ & $\mathrm{O}-\mathrm{H}, \mathrm{N}-\mathrm{H}, \mathrm{C}-\mathrm{H}$ group \\
2 & 3833.16 & $\mathrm{~N}-\mathrm{H}, \mathrm{C}-\mathrm{H}$ stretching & O-H,H, C-H group \\
3 & 3796.18 & $\mathrm{~N}-\mathrm{H}, \mathrm{C}-\mathrm{H}$ stretching $\mathrm{N}-\mathrm{H}, \mathrm{C}-\mathrm{H}$ group \\
4 & 3437.06 & $\mathrm{~N}-\mathrm{H}, \mathrm{C}-\mathrm{H}$ stretching & $\mathrm{O}-\mathrm{H}, \mathrm{N}-\mathrm{H}, \mathrm{C}-\mathrm{H}$ group \\
5 & 2920.92 & $\mathrm{C}-\mathrm{H}$ stretching & $\mathrm{C}-\mathrm{H}$ group \\
6 & 2850.77 & $\mathrm{C}-\mathrm{H}$ stretching & $\mathrm{C}-\mathrm{H}$ group \\
7 & 1816.19 & $\mathrm{C}=\mathrm{O}$ stretching & $\mathrm{C}=\mathrm{O}$ group \\
8 & 1732.88 & $\mathrm{C}=\mathrm{O}$ stretching & $\mathrm{C}=\mathrm{O}$ group \\
9 & 1635.57 & $\mathrm{C}=\mathrm{N}$ stretching & $\mathrm{C}=\mathrm{O} \mathrm{C}=\mathrm{C} \mathrm{C}=\mathrm{N}$ group \\
10 & 1465.57 & $\mathrm{C}=\mathrm{N}$ stretching & $\mathrm{C}=\mathrm{C} \mathrm{C}=\mathrm{N}$ group \\
11 & 1405.93 & $\mathrm{C}=\mathrm{O}$ stretching & $\mathrm{C}=\mathrm{N} \mathrm{C}=\mathrm{C} \mathrm{C}=\mathrm{O}$ group \\
12 & 1384.6 & $\mathrm{C}-\mathrm{N}$ & $\mathrm{C}-\mathrm{O} \mathrm{C}-\mathrm{N}$ group \\
13 & 1115.75 & $\mathrm{C}-\mathrm{C}$ & $\mathrm{C}-\mathrm{O} \mathrm{C}-\mathrm{N} \mathrm{C}-\mathrm{C}$ group \\
14 & 1019.51 & $\mathrm{C}-\mathrm{C}$ & $\mathrm{C}-\mathrm{C}$ group \\
15 & 922.19 & $\mathrm{C}-\mathrm{C}$ & $\mathrm{C}-\mathrm{C}$ group \\
16 & 669.57 & -- & Rock \\
17 & 602.77 & -- & Rock \\
\hline
\end{tabular}

Table 2: Correlation of IR spectra of the compound isolated from Suberites carnosus at Rf value 0.690on TLC

\begin{tabular}{|c|c|c|c|}
\hline S. No. & Wave number: cm-1 intensity & Type of Ir vibrations & Probable group assignment \\
\hline 1 & 3442.81 & $\mathrm{~N}-\mathrm{H}$ stretching & $\mathrm{O}-\mathrm{H}, \mathrm{N}-\mathrm{H}$ group \\
\hline 2 & 3161.69 & C-H stretching & C-H group \\
\hline 3 & 3102.48 & C-H stretching & $\mathrm{C}-\mathrm{H}$ group \\
\hline 4 & 3048.22 & C-H stretching & C-H group \\
\hline 5 & 2923.69 & C-H stretching & C-H group \\
\hline 6 & 2851.45 & C-H stretching & $\mathrm{C}-\mathrm{H}$ group \\
\hline 7 & 1743.77 & C-N stretching & $\mathrm{C}=\mathrm{O}, \mathrm{C}=\mathrm{C}, \mathrm{C}-\mathrm{N}$ group \\
\hline 8 & 1632.55 & C-N stretching & $\mathrm{C}=\mathrm{O}, \mathrm{C}=\mathrm{C}, \mathrm{C}-\mathrm{N}$ group \\
\hline 9 & 1464.36 & - & - \\
\hline 10 & 1414.01 & - & - \\
\hline 11 & 1384.01 & C-N stretching & $\mathrm{C}-\mathrm{O}, \mathrm{C}-\mathrm{N}$ group \\
\hline 12 & 1312.48 & C-O stretching & C-N, C-O group \\
\hline 13 & 1257.32 & $\mathrm{C}-\mathrm{C}$ & C-O, C-N, C-C group \\
\hline 14 & 1204.76 & $\mathrm{C}-\mathrm{C}$ & C-O, C-N, C-C group \\
\hline 15 & 1120.42 & $\mathrm{C}-\mathrm{C}$ & C-O, C-N, C-C group \\
\hline 16 & 1020.18 & $\mathrm{C}-\mathrm{C}$ & C-O, C-N, C-C group \\
\hline 17 & 921.29 & $\mathrm{C}-\mathrm{C}$ & C-O, C-N, C-C group \\
\hline 18 & 863.12 & $\mathrm{C}-\mathrm{C}$ & C-O, C-N, C-C group \\
\hline 19 & 451.47 & - & Rock \\
\hline 20 & 418.50 & - & Rock \\
\hline
\end{tabular}

Characterization of chemical substances from the bioactive samples is generally performed by hyphenated techniques such as GC-MS (Gas chromatography-Mass Spectrometry). The structural features of the biomolecules are confirmed by techniques such as FTIR (Fourier transfer infrared spectroscopy). 
Table 3: Correlation of IR spectra of the compound isolated from Suberites carnosus at Rf value 0.75 on TLC

\begin{tabular}{|c|c|c|c|}
\hline S. No. & Wave number: $\mathrm{cm}^{-1}$ intensity & Type of Ir vibrations & Probable group assignment \\
\hline 1 & 3906.52 & C-H stretching & O-H, N-H,C-H group \\
\hline 2 & 3872.75 & C-H stretching & $\mathrm{O}-\mathrm{H}, \mathrm{N}-\mathrm{H}, \mathrm{C}-\mathrm{H}$ group \\
\hline 3 & 3857.80 & $\mathrm{C}-\mathrm{H}$ stretching & $\mathrm{O}-\mathrm{H}, \mathrm{N}-\mathrm{H}, \mathrm{C}-\mathrm{H}$ group \\
\hline 4 & 3841.55 & $\mathrm{C}-\mathrm{H}$ stretching & $\mathrm{O}-\mathrm{H}, \mathrm{N}-\mathrm{H}, \mathrm{C}-\mathrm{H}$ group \\
\hline 5 & 3825.04 & C-H stretching & $\mathrm{O}-\mathrm{H}, \mathrm{N}-\mathrm{H}, \mathrm{C}-\mathrm{H}$ group \\
\hline 6 & 3807.26 & C-H stretching & $\mathrm{O}-\mathrm{H}, \mathrm{N}-\mathrm{H}, \mathrm{C}-\mathrm{H}$ group \\
\hline 7 & 3752.81 & $\mathrm{C}-\mathrm{H}$ stretching & $\mathrm{O}-\mathrm{H}, \mathrm{N}-\mathrm{H}, \mathrm{C}-\mathrm{H}$ group \\
\hline 8 & 3716.02 & $\mathrm{C}-\mathrm{H}$ stretching & $\mathrm{O}-\mathrm{H}, \mathrm{N}-\mathrm{H}, \mathrm{C}-\mathrm{H}$ group \\
\hline 9 & 3694.32 & C-H stretching & $\mathrm{O}-\mathrm{H}, \mathrm{N}-\mathrm{H}, \mathrm{C}-\mathrm{H}$ group \\
\hline 10 & 3677.32 & $\mathrm{C}-\mathrm{H}$ stretching & $\mathrm{O}-\mathrm{H}, \mathrm{N}-\mathrm{H}, \mathrm{C}-\mathrm{H}$ group \\
\hline 11 & 3655.88 & $\mathrm{C}-\mathrm{H}$ stretching & $\mathrm{O}-\mathrm{H}, \mathrm{N}-\mathrm{H}, \mathrm{C}-\mathrm{H}$ group \\
\hline 12 & 3634.04 & C-H stretching & $\mathrm{O}-\mathrm{H}, \mathrm{N}-\mathrm{H}, \mathrm{C}-\mathrm{H}$ group \\
\hline 13 & 3448.20 & $\mathrm{C}-\mathrm{H}$ stretching & $\mathrm{O}-\mathrm{H}, \mathrm{N}-\mathrm{H}, \mathrm{C}-\mathrm{H}$ group \\
\hline 14 & 3222.35 & C-H stretching & C-H group \\
\hline 15 & 3162.92 & C-H stretching & $\mathrm{C}-\mathrm{H}$ group \\
\hline 16 & 3127.55 & C-H stretching & $\mathrm{C}-\mathrm{H}$ group \\
\hline 17 & 3102.27 & $\mathrm{C}-\mathrm{H}$ stretching & $\mathrm{C}-\mathrm{H}$ group \\
\hline 18 & 3056.90 & C-H stretching & $\mathrm{C}-\mathrm{H}$ group \\
\hline 19 & 3027.57 & C-H stretching & $\mathrm{C}-\mathrm{H}$ group \\
\hline 20 & 2957.45 & C-H stretching & $\mathrm{C}-\mathrm{H}$ group \\
\hline 21 & 2919.55 & C-H stretching & $\mathrm{C}-\mathrm{H}$ group \\
\hline 22 & 2851.01 & $\mathrm{C}-\mathrm{H}$ stretching & $\mathrm{C}-\mathrm{H}$ group \\
\hline 23 & 2766.97 & $\mathrm{C}-\mathrm{H}$ stretching & C-H group \\
\hline 24 & 2655.49 & - & Nitriles carbenes group \\
\hline 25 & 2247.06 & - & Nitriles carbenes group \\
\hline 26 & 1873.98 & $\mathrm{C}=0$ stretching & $\mathrm{C}=0$ group \\
\hline 27 & 1833.96 & $\mathrm{C}=\mathrm{N}$ stretching & $\mathrm{C}=\mathrm{O}, \mathrm{C}=\mathrm{C}, \mathrm{C}=\mathrm{N}$ group \\
\hline 28 & 1801.39 & $\mathrm{C}=\mathrm{N}$ stretching & $\mathrm{C}=\mathrm{O}, \mathrm{C}=\mathrm{C}, \mathrm{C}=\mathrm{N}$ group \\
\hline 29 & 1782.77 & $\mathrm{C}=\mathrm{N}$ stretching & $\mathrm{C}=\mathrm{O}, \mathrm{C}=\mathrm{C}, \mathrm{C}=\mathrm{N}$ group \\
\hline 30 & 1738.30 & $\mathrm{C}=\mathrm{N}$ stretching & $\mathrm{C}=\mathrm{O}, \mathrm{C}=\mathrm{C}, \mathrm{C}=\mathrm{N}$ group \\
\hline 31 & 1629.54 & $\mathrm{C}=\mathrm{N}$ stretching & $\mathrm{C}=\mathrm{O}, \mathrm{C}=\mathrm{C}, \mathrm{C}=\mathrm{N}$ group \\
\hline 32 & 1547.58 & $\mathrm{C}=\mathrm{N}$ stretching & $\mathrm{C}=\mathrm{O}, \mathrm{C}=\mathrm{C}, \mathrm{C}=\mathrm{N}$ group \\
\hline 33 & 1528.08 & $\mathrm{C}=\mathrm{N}$ stretching & $\mathrm{C}=\mathrm{O}, \mathrm{C}=\mathrm{C}, \mathrm{C}=\mathrm{N}$ group \\
\hline 34 & 1511.70 & $\mathrm{C}-\mathrm{C}-$ & $\mathrm{C}-\mathrm{O}, \mathrm{C}-\mathrm{N}, \mathrm{C}-\mathrm{C}$ group \\
\hline 35 & 1465.12 & $\mathrm{C}-\mathrm{C}-$ & $\mathrm{C}-\mathrm{O}, \mathrm{C}-\mathrm{N}, \mathrm{C}-\mathrm{C}$ group \\
\hline 36 & 1409.68 & $\mathrm{C}-\mathrm{C}-$ & $\mathrm{C}-\mathrm{O}, \mathrm{C}-\mathrm{N}, \mathrm{C}-\mathrm{C}$ group \\
\hline 37 & 1383.44 & $\mathrm{C}-\mathrm{C}-$ & $\mathrm{C}-\mathrm{O}, \mathrm{C}-\mathrm{N}, \mathrm{C}-\mathrm{C}$ group \\
\hline 38 & 1312.70 & $\mathrm{C}-\mathrm{C}-$ & $\mathrm{C}-\mathrm{O}, \mathrm{C}-\mathrm{N}, \mathrm{C}-\mathrm{C}$ group \\
\hline 39 & 1217.68 & $\mathrm{C}-\mathrm{C}-$ & C-C group \\
\hline 40 & 1179.53 & $\mathrm{C}-\mathrm{C}-$ & C-C group \\
\hline 41 & 1120.83 & $\mathrm{C}-\mathrm{C}-$ & C-C group \\
\hline 42 & 1020.05 & $\mathrm{C}-\mathrm{C}-$ & C-C group \\
\hline 43 & 925.70 & $\mathrm{C}-\mathrm{C}-$ & C-C group \\
\hline 44 & 859.21 & $\mathrm{C}-\mathrm{C}-$ & C-C group \\
\hline 45 & 802.55 & $\mathrm{C}-\mathrm{C}-$ & C-C group \\
\hline 46 & 748.59 & - & Rock \\
\hline 47 & 722.06 & - & Rock \\
\hline 48 & 675.81 & - & Rock \\
\hline 49 & 659.97 & - & Rock \\
\hline
\end{tabular}

A total of 146 natural products from various marine sponges belonging to the genus Hyrtios were reported in Marin literature database until 2016 [9]. During the year 1998, Hattori demonstrated new ceramide compound from marine sponge. Possible biogenetic relevance with Manzamine portrayed novel lipid contents of the sponge Haliclona $s p$. Sponges production a broad array of additional metabolites ranging across by-products of amino acids and porphyrins, nucleosides to macrolides, aliphatic cyclic peroxides, terpenoids and sterols [10]. Consistently, [11] proposed the new antifouling hexapeptide from a Palauan sponge, Haliclona sp. The study depicted [12] showed that the chromatogram stands for compounds elucidation by GC-MS on the methanol extract experimental sponge of Ircinia fusca. Initially nine compounds were categorized. Among the nine compounds, two antimicrobial compounds are present such as 2-Methoxy1, 4-Benzenediol recognized as a peak compound subsequently 3-dimethylocta-1, 5dien-3, 7-dioldimethyltryptamine also been elucidated. The antinociceptive and anti-inflammatory effects are investigated beyond different experimental fig. in mice described by [13], also this author explained the sponge Caissera possessed antinoceptive and antiedematogenic effects. According to them, that was the first study which described the marine sponge extract could be resisting them propagation of microbiota present in CSF shunt infection. Since the structurally derived chemical compounds were [14] explained marine natural products halitoxin, toxic composite of different marine sponges of the genus Haliclona. Furthermore [15] demonstrated similar findings with other pathogenic microbes and its constructive valuable pharmacological compounds such as Araguspongines- $\mathrm{K}$ and $\mathrm{l}$, current bioactive bis, oxaquinolizidine noxide alkaloids against red Sea specimens of Xestospongia exigua. This study explained the eighth experimental sponge possessed the peak bioactive compound named as 2-Methoxy-1, 4-Benzenediol is act as an antimicrobial compound so this particular sponge activity is high compared with other seven sponges. The similar kinds of findings have also been published by [16]. Pharmaceutically important Phytochemicals originated from sponge $[17,18]$ reported 
inhibition of HIV by two bis-quinolizidine alkaloids petrosins isolated from the Indian marine sponge Petrosia similis. The extensive investigations are determined that both petrosins inhibited HIV-1 replications. The study carried out by the [19] with the biological action of aqueous explore from marine sponges and cytotoxic goods of 3 alkyl pyridinium polymers against Reniera sarai and be of the same opinion depicted by [20] in the marine parasite of the genus Ircinia against few peculiar human affected pathogenic organisms. Potential studies of a larger patent population will be needed to determine the relationships between the divers CSF affected microbiota and clinical outcomes, particularly the response to treatment and occurrence of reinfection [21-23]. The study carried out by [24] reported the gorgosterol type sterol lacking methyl substitution of the cyclopropane ring system, namely 22,23methylene (22S, 23S) cholesterol 3 along with known compounds have been identified from marine sponge Sigmadocia fibulata. Previous work on this sponge reported steroid mixtures [25] and peptides [26] for the first time.

Table 4: Correlation of IR spectra of the compound isolated from Suberites carnosus at Rf value 0.89on TLC

\begin{tabular}{|c|c|c|c|}
\hline S. No. & Wave number: cm-1 intensity & Type of Ir vibrations & Probable group assignment \\
\hline 1 & 3863.44 & - & - \\
\hline 2 & 3846.98 & - & - \\
\hline 3 & 3814.28 & - & - \\
\hline 4 & 3744.37 & $\mathrm{~N}-\mathrm{H}$ stretching & $\mathrm{O}-\mathrm{H}, \mathrm{N}-\mathrm{H}$ group \\
\hline 5 & 3667.79 & N-H stretching & $\mathrm{O}-\mathrm{H}, \mathrm{N}-\mathrm{H}$ group \\
\hline 6 & 3641.03 & N-H stretching & $\mathrm{O}-\mathrm{H}, \mathrm{N}-\mathrm{H}$ group \\
\hline 7 & 3439.91 & $\mathrm{~N}-\mathrm{H}$ stretching & $\mathrm{O}-\mathrm{H}, \mathrm{N}-\mathrm{H}$ group \\
\hline 8 & 3159.90 & C-H stretching & $\mathrm{C}-\mathrm{H}$ group \\
\hline 9 & 3101.96 & C-H stretching & $\mathrm{C}-\mathrm{H}$ group \\
\hline 10 & 3048.80 & C-H stretching & $\mathrm{C}-\mathrm{H}$ group \\
\hline 11 & 2950.59 & C-H stretching & $\mathrm{C}-\mathrm{H}$ group \\
\hline 12 & 2924.98 & $\mathrm{C}-\mathrm{H}$ stretching & $\mathrm{C}-\mathrm{H}$ group \\
\hline 13 & 2841.17 & C-H stretching & $\mathrm{C}-\mathrm{H}$ group \\
\hline 14 & 2767.07 & C-H stretching & $\mathrm{C}-\mathrm{H}$ group \\
\hline 15 & 2711.97 & C-H stretching & $\mathrm{C}-\mathrm{H}$ group \\
\hline 16 & 2655.20 & - & - \\
\hline 17 & 2600.95 & - & - \\
\hline 18 & 2543.98 & - & Nitriles carbenes group \\
\hline 19 & 2489.42 & - & Nitriles carbenes group \\
\hline 20 & 2246.14 & - & Nitriles carbenes group \\
\hline 21 & 1800.13 & $\mathrm{C}=\mathrm{N}$ stretching & $\mathrm{C}=\mathrm{O}, \mathrm{C}=\mathrm{C}, \mathrm{C}=\mathrm{N}$ group \\
\hline 22 & 1741.57 & $\mathrm{C}=\mathrm{N}$ stretching & $\mathrm{C}=\mathrm{O}, \mathrm{C}=\mathrm{C}, \mathrm{C}=\mathrm{N}$ group \\
\hline 23 & 1708.13 & $\mathrm{C}=\mathrm{N}$ stretching & $\mathrm{C}=\mathrm{O}, \mathrm{C}=\mathrm{C}, \mathrm{C}=\mathrm{N}$ group \\
\hline 24 & 1640.77 & $\mathrm{C}=\mathrm{N}$ stretching & $\mathrm{C}=\mathrm{O}, \mathrm{C}=\mathrm{C}, \mathrm{C}=\mathrm{N}$ group \\
\hline 25 & 1566.93 & $\mathrm{C}=\mathrm{N}$ stretching & $\mathrm{C}=\mathrm{O}, \mathrm{C}=\mathrm{C}, \mathrm{C}=\mathrm{N}$ group \\
\hline 26 & 1549.42 & $\mathrm{C}=\mathrm{N}$ stretching & $\mathrm{C}=\mathrm{O}, \mathrm{C}=\mathrm{C}, \mathrm{C}=\mathrm{N}$ group \\
\hline 27 & 1530.80 & $\mathrm{C}=\mathrm{N}$ stretching & $\mathrm{C}=\mathrm{O}, \mathrm{C}=\mathrm{C}, \mathrm{C}=\mathrm{N}$ group \\
\hline 28 & 1514.34 & $\mathrm{C}=\mathrm{N}$ stretching & $\mathrm{C}=\mathrm{O}, \mathrm{C}=\mathrm{C}, \mathrm{C}=\mathrm{N}$ group \\
\hline 29 & 1464.83 & - & - \\
\hline 30 & 1409.78 & - & - \\
\hline 31 & 1383.60 & C-N stretching & C-O, C-N group \\
\hline 32 & 1313.43 & C-N stretching & $\mathrm{C}-\mathrm{O}, \mathrm{C}-\mathrm{N}$ group \\
\hline 33 & 1258.94 & C-N stretching & $\mathrm{C}-\mathrm{O}, \mathrm{C}-\mathrm{N}$ group \\
\hline 34 & 1215.63 & C-N stretching & C-O, C-N group \\
\hline 35 & 1118.16 & $\mathrm{C}-\mathrm{O}$ & C-C, C-N,C-O group \\
\hline 36 & 1021.91 & $\mathrm{C}-\mathrm{O}$ & C-C, C-N, C-O group \\
\hline 37 & 920.66 & $\mathrm{C}-\mathrm{C}$ & C-C group \\
\hline 38 & 864.00 & $\mathrm{C}-\mathrm{C}$ & C-C group \\
\hline 39 & 804.22 & $\mathrm{C}-\mathrm{C}$ & C-C group \\
\hline 40 & 751.75 & - & Rock \\
\hline 41 & 692.91 & - & Rock \\
\hline 42 & 672.30 & - & Rock \\
\hline 43 & 600.43 & - & Rock \\
\hline 44 & 496.55 & - & Rock \\
\hline 45 & 466.82 & - & Rock \\
\hline 46 & 414.20 & - & Rock \\
\hline
\end{tabular}

In the present work, GC-MS, and FTIR techniques have been employed and the results obtained are presented and discussed here as follows:

GC-MS is an analytical technique. In this, GC (gas chromatography) and MS (mass spectrometer) are coupled together by an interface arrangement. GC helps to separate the individual molecules of the sample and the MS identifies each component through the fragmentation patterns obtained by each molecule by the library database of the mass spectrometer. The authenticity of these molecules was then confirmed by repeating the GC-MS studies by using the standard reference materials. The gas chromatograms shown in fig, 3 to 6 indicates that a large number of components are present in each of the isolated extracts Suberites carnosus (Johnston). However, for the present study, we have selected the components of GC peaks at Rt values of of Suberites carnosus (Johnston) are 14.34; $15.35 ; 15.45 ; 16.76 ; 27.63 ; 28.21 ; 4.17 ; 6.49 ; 19.93$; and 12.36 only, because they gave some conclusive evidence to identify the nature of the components on the database library and by using reference book by [9]. Therefore, the respective eluents at these Rt values were irradicated into the Electron impact (EI) source of the mass spectrometer by which the molecules loose one electron and form positively charged molecules. Thus the molecules separate in ion trap mass spectrometer. The MS peaks shown in fig. 8 to 17 , indicate 
that the mass peaks are due to the compounds having molecular weight of Suberites carnosus are 352, 364, 455, 608,340, 330, 470, 366,322 , and 702 , respectively. These mass spectra are correlate to the mass spectra are 6-Fluoro 2-trifluromethylbenzoic acid,2,3dichlorophenyl ester, Eicosane 3-cyclohexyl, Phosphine imide,
$\mathrm{P}, \mathrm{P}, \mathrm{P}$,-tris (p-chlorophenyl)-N-phenyl-, Dimethylhyl hexavinyl octasilsesquioxane, Hexanoicacid, hexadecyl ester, Hexadecanoic acid,2-hydroxy1-(hydroxymethyl)ethyl ester, 9, 19-Cyclolanostan-3ol, acetate, $(3 \beta)$, Tetracosane, 3-ethyl-, 11, 14-Eicosadienoic acid, methyl ester, Triacontane, 11,20-didecyl-respectively.

\section{Table 5: Showing name of the compound molecular weight, molecular formula, and structure of the compounds isolated from Suberites} carnosus (Johnston)

\begin{tabular}{|c|c|c|c|c|}
\hline S. No. & Name of the compound & Molicular weight & Molecular formula & Structure \\
\hline \multicolumn{5}{|c|}{ Suberites carnosus (Johnston) } \\
\hline 1 & $\begin{array}{l}\text { 6-Fluoro 2-trifluromethylbenzoic } \\
\text { acid,2,3-dichlorophenyl ester }\end{array}$ & MW-352 & $\mathrm{C}_{14} \mathrm{H}_{6} \mathrm{C}_{12} \mathrm{~F}_{4} \mathrm{O}_{2}$ & \\
\hline 2 & Eicosane 3-cyclohexyl & MW-364 & $\mathrm{C}_{26} \mathrm{H}_{52}$ & \\
\hline 3 & $\begin{array}{l}\text { Phosphine imide, P,P,P,-tris (p- } \\
\text { chlorophenyl)-N-phenyl- }\end{array}$ & MW-455 & $\mathrm{C}_{24} \mathrm{H}_{17} \mathrm{C}_{13} \mathrm{NP}$ & \\
\hline 4 & $\begin{array}{l}\text { Dimethylhyl hexavinyl } \\
\text { octasilsesquioxane }\end{array}$ & MW-608 & $\mathrm{C}_{14} \mathrm{H}_{24} \mathrm{O}_{12} \mathrm{Si}_{8}$ & \\
\hline 5 & Hexanoicacid, hexadecyl ester & MW-340 & $\mathrm{C}_{22} \mathrm{H}_{44} \mathrm{O}_{2}$ & \\
\hline 6 & $\begin{array}{l}\text { Hexadecanoic acid,2-hydroxy 1- } \\
\text { (hydroxymethyl)ethyl ester }\end{array}$ & MW-330 & $\mathrm{C}_{19} \mathrm{H}_{38} \mathrm{O}_{4}$ & oH \\
\hline 7 & $\begin{array}{l}\text { 9,19-Cyclolanostan-3-ol, } \\
\text { acetate, }(3 \beta)\end{array}$ & MW-470 & $\mathrm{C}_{32} \mathrm{H}_{54} \mathrm{O}_{2}$ & \\
\hline 8 & Tetracosane, 3-ethyl & MW-366 & $\mathrm{C}_{26} \mathrm{H}_{54}$ & \\
\hline 9 & $\begin{array}{l}\text { 11,14-Eicosadienoic acid, methyl } \\
\text { ester }\end{array}$ & MW-322 & C21H38O2 & \\
\hline 10 & Triacontane, 11,20-didecyl- & MW-702 & $\mathrm{C} 50 \mathrm{H} 102$ & \\
\hline
\end{tabular}

\section{CONCLUSION}

From the above results, it was found that some of the compounds have antibacterial, anti-fungal and marine irritant properties. Therefore it concludes that, the compounds extracted from sponge Suberites carnosus showed antibacterial, pesticidal, and biomedical properties. Our findings are significant for the development of multidrug therapy for both pharmaceuticals and biomedical applications. The study further suggests that, Suberites carnosus, further screening is required for molecular level to understand the physiology and mode of action of the compound. The clinical study is also required which may be useful for pharmaceutical industry to manufacture the new drugs for safe performance and safety indexes to be studied to eradicate the diseases.

\section{ACKNOWLEDGEMENT}

Authors would like to thank to, Dr. P. A. Thomas, Principal Scientist, Central Marine Fisheries Research Institute (CMFRI), Thiruvananthapuram, Kerala for the identification of sponge species. Authors are also thanks to, The Director, APT Testing and Research Pvt. Ltd. (ATR) Pune, for experimentation and providing their assistance (IAEC NO. APTRF/RP 57/1819 dated 01 February 2019).
Thanks is also due to The Director, Ancrom test lab. Mulund, Mumbai, for providing HPTLC (High-Performance Thin Layer Chromatography) facilities and also to the Director, (SAIF) IIT, Powai, Mumbai for providing the facilities of analytical study.

\section{AUTHORS CONTRIBUTIONS}

N. S Bhadeker is the Ph. D. student and Dr. G. V. Zodape is the Guide and corresponding author. The research student have carried out her research work for the award of $\mathrm{Ph}$. D. Degree under the supervision and guidance of Corresponding author.

\section{CONFLICT OF INTERESTS}

There is no conflict of interest

\section{REFERENCES}

1. McConnell OJ, Longley RE, Koehn FE. The discovery of marine natural products with therapeutic potential. Biotechnology 1994;26:109-74.

2. Newbold RW, Jensen PR, Fenical W, Pawlik JR. Antimicrobial activity of caribbean sponge extracts. Aquat Microb Ecol 1999;19:279-84 
3. Selvin J, Lipton AP. Biopotentials of secondary metabolites isolated from marine sponges. Hydrobiologia 2004;513:231-8.

4. Thomas PA. Porifera. In: Alfred JRB, Das AK, Sanyal AK. editors Faunal diversity in India. Calcutta: ENVIS Central Zoological Survey of India; 1998. p. 28-36.

5. Tilvi S, Naik CG. Tandem mass spectrometry of kahalalides: identification of two new cyclic depsipeptides, kahalalide $r$ and s from Elysia grandifolia. J Mass Spectrom 2007;42:70-80.

6. Vankateshwaran. Microchemolytic assay P-41-42 in laboratory manual on advanced techniques in marine biotoxinology (Venka K. and Pani Prasad K. Ed) CAS in Fishery science. CIFE Mumbai India; 1997. p. 76.

7. Zodape GV, Kulkarni BG. Occurrence of anatoxin-a and homoanatoxin-a in intertidal crab Leptodius exratus in Mumbai nariman point coast. Bionano Frontier 2010;3:259-64.

8. Braekman JC, Daloze D, Stoller C, Van Soest RWM. Chemotaxonomy of agelas (Porifera: demospongiae). Biochem Syst Ecol 1992;20:417-31.

9. Shady Nourhan Hisham, El-Hossary Ebaa M, Fouad Mostafa A Gulder Tobias AM, Mohamed Salah Kamel, Abdelmohsen Usama Ramadan. Bioactive natural products of marine sponges from the genus hyrtios. Molecules 2017;22:781.

10. Masry-El HA, Fahmy HH, Abdelwahed, ASH. Synthesis and antimicrobial activity of some new benzimidazole derivatives. Molecules 2000;5:1429-38.

11. Havard Fan P, Nahata MC. Treatment and prevention of infections of cerebrospinal fluid shunts. Clin Pharm 1987;6:866-80.

12. Sujatha S, Prakash Vincent G, Jobi Dhas M. Marine sponge and its potential bioactive spectrum against CSF affected bacterial organisms. Pharma Innovation J 2014;3:81-6.

13. Azevedo LG, Peraza GG, Lerner C, Soares A, Murcia N, Muccillo $\mathrm{BA}$, et al. Investigation of the anti-inflammatory and analgesic effects from an extract of Aplysina caissara, a marine sponge. Fundament Clin Pharmacol 2008;22:549-56.

14. Oliveira JHD, Grube A, Kock M, Berlinck RG, Macedo ML, Ferreira AG, et al. Ingenamine G and cyclostellettamines G-I, K, and $\mathrm{L}$ from the new Brazilian species of marine sponge pachychalina sp. J Nat Prod 2004;67:1685-9.

15. Joseph B, Sujatha S. Pharmacologically important natural products from marine sponges. J Nat Prod 2010;4:5-12.

16. Buchanan MS, Edser KG, Whitmore J, Quinn RJ. Cheilanthane sesterterpenes, protein kinase inhibitors, from a marine sponge of the genus. Ircinia J Nat Prod 2001;64:300-3.

17. Blunt JW, Copp BR, Munro MHG, Northcote PT, Prunes MR Marine natural products Nat Prod Rep 2006;23:26-78.

18. Groud TV, Reddy NS, Swamy NR, Ram TS, Venkateswarlu Y Anti-HIV active petrosins from the marine sponge Petrosia similis. Biol Pharm Bull 2003;26:1498-501.

19. Kristina Sepcic Silke Kauferstein, Dietrich Mebs, Tom Turk Biological activities of aqueous and organic extracts from tropical marine sponges. Mar Drugs 2010;8:1550-66.

20. Chelossi E, Mancini I, Sepcic K, Turk T, Faimali M. Comparative antibacterial activity of polymeric 3-alkylpyridinium salts isolated from the Mediterranean sponge Reniera sarai and their synthetic analogues. Biomol Eng 2006;23:317-23.

21. Fan Havard P, Nahata MC. Treatment and prevention of infections of cerebrospinal fluid shunts. Clin Pharm 1987;6:866-80.

22. Fux CA, Quigley M, Worel AM, Post C, Zimmerli S. Biofilmrelated infections of cerebrospinal fluid shunts. Clin Microbiol Infect 2006;12:331-7.

23. Vinchon M, Dhellemmes P. Cerebrospinal fluid shunt infection: risk factors and long-term follow-up. Childs Nerv Syst 2006;22:692-7.

24. Thota SPR, Sarma NS, Murthy YLN. Occurrence of a rare gorgosterol type steroid in marine sponge Sigmadocia fibulata. J Nat Prod 2015;8:5-8.

25. Lo JM, Wang WL, Chiang YM, Chen CM. Ceramides from the taiwan red alga $C$. spongiosum and symbiotic sponge $S$. symbiotica. J Chinese Chem Soc 2001;8:821.

26. Tan LT, Williamson RT, Gerwick WH, Watts KS, McGough K, Jacob R. Cis, cis-and trans, trans-ceratospongamide, new bioactive cyclic heptapeptides from the Indonesian red alga Ceratodictyon spongiosum and symbiotic sponge Sigmadocia symbiotica. J Org Chem 2000;65:419. 